\title{
IMPACT OF ENGINE EMISSIONS FROM HCCI ENGINE: AN OVERVIEW
}

\section{A.DEVARAJ, I.VINOTHKANNA, K.MANIKANDAN \& JISHUCHANDRAN}

Assistant Professor, Department of Mechanical Engineering, Veltech Dr.RR \& Dr.SR University, Chennai, India

ABSTRACT
Homogenous Charge Compression Engine (HCCI) runs in advanced mode of combustion were no spark plug
or fuel injector is needed to initiate the combustion. When the chemical energy of the fuel attains its excited level (auto-
ignition), air-fuel mixture gets auto-ignites in multiple spots of the combustion chamber. HCCI combustion process is
faster than conventional Compression Ignition (C. I) and Spark Ignition (S. I) engines. Main advantage of using HCCI
technology is to attain better thermal efficiency and maintains low emission by modifying S. I and C. I engines than
conventional C. I and S. I engines. Objective of this review is to study the emission characteristics of HCCI at different
test conditions and challenges faced to attain HCCI combustion.
KEYWORDS: Combustion, Chemical, HCCI, \& Ignition

Received: Nov 03, 2017; Accepted: Nov 23, 2017; Published: Dec 01, 2017; Paper Id.: IJMPERDDEC201757

\section{INTRODUCTION}

I. C engines were used globally for transportation, industry and agriculture purpose as a prime mover, but the emissions produced by the engines are more harmful to humans and environment. HCCI engine is a new mode of combustion and has a potential to reduce a harmful emission compared to S.I and C.I engines. Homogenous airfuel mixture is compressed until the auto ignition occurs near the end of the compression stroke is called as HCCI combustion. Combustion process can be done by combination of conventional fuel and alternative fuels. Normally HCCI engines follow lean air fuel mixture.

Port fuel injection and vaporizer method is known as external mixture preparation. Port fuel injection can be used when the fuel has high latent heat of vaporization, octane number more than gasoline and diesel. In vaporizer method, fuel and air gets homogenous mixture by an external heater and then get inducted in the intake manifold. Internal mixture preparation strategies can be called as early, late and multiple direct injection system. When the injection systems are taking place into two stages, it is called combined external and internal mixture preparation, most of the fuel is injected in the intake manifold and this pre-mixture gets ignited in the combustion chamber by small amount of fuel directly inside the cylinder.

HCCI engine is combined mode of Spark Ignition (Homogenous charge Spark Ignition) and Compression Ignition (stratified charge compression ignition) engines. HCCI engine follows the homogenous mixture of airfuel in which fuel is injected well before the combustion event; this mixture initiates the combustion simultaneously at different location of the combustion chamber unlike S.I (flame Propagation) or C.I (locally Rich flame front) engine.

Pucher GR [1] et al, by using the diesel fuel, HCCI combustion occurs in two stage heat release. A low temperature kinetic reaction is called as first stage, while heat release regime is called as Second stage. Auto 
ignition stage is controlled by low temperature chemistry and main heat release is dominated by co-oxidation. By achieving the $\mathrm{HCCI}$ combustion there is a reduction of Nitrogen Oxide $\left(\mathrm{NO}_{\mathrm{x}}\right)$ and Soot in the engine exhaust. Although, the performance characteristic is good in HCCI combustion, controlling the combustion phase has led the major challenge to the researches. So the researchers were trying different combustion control strategies [2].

Port fuel injection, Early direct injection, late direct injection, multiple fuel injection, compound combustion technology, Narrow angle injection, multiple fuel injection, variable inlet temperature and variable valve timing, internal and external Exhaust Gas Recirculation (EGR). Heywood [3] has explained the HCCI combustion by comparing with conventional C. I engine which gives high particulate matter and soot emission, this is because of rich air-fuel mixture and diffusion rich regions. By using $\mathrm{HCCI}$ combustion technology this can be overcome. HCCI combustion follows volumetric combustion and low temperature combustion, which results in low particulate and soot formation.

Onishi et al [4], conducted experiment on conventional S.I Engine in both S.I and HCCI modes, using Schliren Photography method, to visualize the process of combustion. They concluded, when the engine is running in S. I mode visible was found but in HCCI mode, there is no visible propagation of flame. This showed that HCCI combustion follows volumetric combustion. In recent years, Hybrid combustion process called Homogenous Charge Compression Ignition Engines (HCCI), attaining with advanced low temperature combustion when comparing with conventional S. I and C. I engines. Need of HCCI engine, to overcome the low part load efficiency and high Carbon monoxide (CO) emission in S.I engine. In C.I engines the amount of nitrogen oxides and particulate matters are high, due to stringent emission norms combination of S.I and C.I technology were developed and names as HCCI engine. HCCI engines have good performance characteristics and ultra low $\mathrm{NO}_{\mathrm{x}}$, particulate emissions.

Atkins MJ et al [5], compressed lean air-fuel mixture gets auto ignited gives the benefits of HCCI engines. Control measures to be followed in HCCI are low specific output, narrow operating range, lack of control over the ignition process, cold starting. Mixture formation in HCCI combustion can be categorized into external, internal and combined mixed preparations. Port fuel injection and fuel vaporiser can be called as external mixture preparations. Early, late and multi direct injection can be said as internal mixture preparation.

Spark Ignition (S.I) engines can be replaced by C.I engine to reduce $\mathrm{CO}_{2}$ emission in effect of global climate change. In addition to that $\mathrm{NO}_{\mathrm{x}}$ and PM emission can further reduce, by advanced combustion technique called $\mathrm{HCCI}$ and to improve the performance characteristics. Gasoline Direct Injection (GDI) or Direct Injection Spark Ignition (DISI) is based on the mixture preparation of spark ignition engine, before the compression process. In the compression process, premixed mixture ignites and the combustion can be treated as an advanced combustion technique called HCCI [6, 7].

$\mathrm{Lu} \mathrm{X}$ et al [8]. has described about fuel design and management for the control of advanced compression ignition combustion modes. They reported HCCI, Stratified charge compression ignition (SCCI) as prominent Low temperature Combustion (LTC) ignition systems.

Sexana and Bedoya [9], reviewed the concepts of affecting low temperature combustion and HCCI engine with their control strategies over load limits. They highlighted LTC engine is the emerging technology that, offers an alternative to S.I and C.I engines. They shown HCCI engine as LTC technology that includes Reactivity Controlled Compression Ignition(RCCI), duel fuel HCCI, Partial fuel stratification(PES), and Spark assisted HCCI(SI-HCCI). To enhance the control strategies of HCCI engine, they discussed several technologies including delayed combustion timing, PES, LTC 
with double injection; promising way to achieve low NOx and Particulate Matter (PM) simultaneously, with advanced combustion process like LTC, which includes HCCI, Premixed Charge Compression Ignition (PCCI). The challenges faced by the $\mathrm{HCCI}$ for mass production are combustion phase control, improving operating range, mixture in homogenous form, cold start efficiency, less emissions compared to S.I and C.I engines [10, 11]

Bendu. A et al [12], reviewed a mixture preparation and control strategies of HCCI technologies of diesel engines. They given two possible methods to control combustion phase in HCCI engines: altering the mixture formation and altering the time-temperature history. Correct mixture formation depends on the properties of the fuel by blending two or more fuels by fuel precondition, EGR and using fuel additives.

Imtenan S et al [13]., reported an critical review on, impact of low temperature combustion and attaining strategies on diesel and biodiesel as a fuel. LTC concept has been achieved, by using HCCI, PCCI and RCCI technique. They showed in LTC modes simultaneous reduction, in NOx and PM and increase in Unburned Hydrocarbon (UHC) and $\mathrm{CO}$ emission has attained while reducing the in cylinder temperature in the combustion chamber. Johanson [14] discussed fuels and combustion. He reported combustion process in S.I engines as premixed flame, C.I engines as diffusion flame and HCCI engine as bulk auto ignition of a premixed charge. He called advanced combustion into spark assisted compression ignition (SACI), PPC, RCCI, duel fuel combustion(DFC), pre-chamber flame ignition, pilot assisted compression ignition(PACI), diesel pilot combustion (DPC).

Hasan et al [15], has compared the HCCI with conventional C.I engine combustion and reported the advantage over the C.I engines, challenges and solution of HCCI engine. Challenges faced by the HCCI combustion includes combustion phase control, addressing the high noise levels finding optimum operating range, managing cold starts and forming homogenous charge preparation.

Musculus et al [16]., discussed the advanced combustion technology involves, superior performance characteristics and to minimize CO2, NOx, PM over conventional S.I and C.I engines. These can be achieved by using low temperature technique.

\begin{tabular}{|c|c|c|c|c|c|}
\hline Reference & Engine Tested & HCCI Method & Base Fluid & $\%$ of EGR & Emission Findings \\
\hline [17], & $\begin{array}{l}\text { 1-cylinder, 4S, AC, NA, } \\
\text { CI, DI, CR: 17:1, RS: } \\
2200 \mathrm{rpm}\end{array}$ & $\begin{array}{l}\text { External Mixture } \\
\text { Preparation. }\end{array}$ & Hydrogen & $\operatorname{EGR}(0-60 \%)$ & $\begin{array}{l}\text { Negligible NOx }=0.01 \mathrm{~g} / \mathrm{KWh} \\
\mathrm{CO}=0.0 \mathrm{~g} / \mathrm{KWh} \\
\text { Particulate matter }=0.00 \mathrm{~g} / \mathrm{KWh} \\
\text { Unburned } \mathrm{HC}=0.02 \mathrm{~g} / \mathrm{KWh}\end{array}$ \\
\hline$[18]$ & $\begin{array}{l}\text { 1-cylinder, 4S, WC, CI, } \\
\text { DI, CR: } 16: 1, \mathrm{RP}: 3.7 \\
\text { kW, RS: } 1500 \mathrm{rpm}\end{array}$ & $\begin{array}{l}\text { External Mixture } \\
\text { Preparation. }\end{array}$ & Acetylene & $\operatorname{EGR}(0-60 \%)$ & $\begin{array}{l}\text { NOx reduced to 20ppm } \\
\text { Smoke level reduced below } 0.1 \mathrm{BSU} \\
\mathrm{HC} \text { is increased to } 2000 \mathrm{ppm}\end{array}$ \\
\hline$[19]$ & $\begin{array}{l}\text { 1-cylinder, } 4 \mathrm{~S}, \mathrm{CI}, \mathrm{DI}, \\
\text { CR: } 17.5: 1 \mathrm{RP}: 4.4 \mathrm{~kW} \\
\text { RS: } 1500 \mathrm{rpm}\end{array}$ & $\begin{array}{l}\text { External Mixture } \\
\text { Preparation. }\end{array}$ & Biodiesel-diesel blend & EGR $(0 \%, 10 \%, 20 \%$ and $30 \%)$ & $\begin{array}{l}81 \% \text { reduction in NOx, } 72 \% \\
\text { reduction in smoke emission, slight } \\
\text { decrease in } \mathrm{HC} \& \mathrm{CO} .\end{array}$ \\
\hline$[20]$ & $\begin{array}{l}\text { 1-cylinder, } 4 \mathrm{~S}, \mathrm{NA}, \mathrm{CI}, \\
\text { DI, CR: } 18.4: 1\end{array}$ & Late injection. & Biodiesel-diesel blend & $\operatorname{EGR}(0 \%, 11.5 \%, 16.6 \%$ and $24.3 \%)$ & Smoke reduced, \\
\hline$[21]$ & $\begin{array}{l}\text { 2-cylinder, } 4 \mathrm{~S}, \mathrm{AC}, \mathrm{CI}, \\
\text { DI, CR: } 16.5: 1, \mathrm{RP}: 5.85 \\
\text { kW, RS: } 1500 \mathrm{rpm}\end{array}$ & $\begin{array}{l}\text { External Mixture } \\
\text { Preparation. }\end{array}$ & Biodiesel-diesel blend & EGR $(0 \%, 15 \%$ and $30 \%)$ & $\begin{array}{l}\text { Minor increase in } \mathrm{CO}, \mathrm{HC} \text { and } \\
\text { smoke. Significant reduction in } \\
\text { NOx. }\end{array}$ \\
\hline$[22]$ & $\begin{array}{l}\text { 1-cylinder, } 4 \mathrm{~S}, \mathrm{WC}, \mathrm{NA}, \\
\text { CI, CR: } 14.8: 1\end{array}$ & $\begin{array}{l}\text { By using Intemal and } \\
\text { External EGR }\end{array}$ & Diesel & EGR $(0 \%, 29 \%, 42 \%$ and $50 \%)$ & $\begin{array}{l}\text { Cooled EGR reduced NOx and } \\
\text { smoke, CO emission increased }\end{array}$ \\
\hline [23] & $\begin{array}{l}\text { 1-cylinder, } 4 \mathrm{~S}, \mathrm{AC}, \mathrm{CI} \\
\text { DI, CR: } 17.5: 1, \mathrm{RP}: 4.4 \\
\mathrm{~kW}, \mathrm{RS}: 1500 \mathrm{rpm}\end{array}$ & $\begin{array}{l}\text { External Mixture } \\
\text { Preparation }\end{array}$ & Diesel & EGR $(0 \%, 10 \%, 20 \%$ and $30 \%)$ & $\begin{array}{l}\text { With } 30 \% \text { EGR optimum, NOx and } \\
\text { smoke were reduced. CO and HC } \\
\text { were increased. }\end{array}$ \\
\hline$[24]$ & $\begin{array}{l}\text { 2-cylinder, 4S, AC, CI, } \\
\text { DI, CR: } 16.5: 1, \mathrm{RP}: 4.85 \\
\text { kW, RS: } 1500 \mathrm{rpm}\end{array}$ & $\begin{array}{l}\text { External Mixture } \\
\text { Preparation }\end{array}$ & Diesel & EGR $(0 \%, 10 \%$ and $20 \%)$ & NOx decreased \\
\hline$[25]$ & $\begin{array}{l}\text { 1-cylinder, } 4 \mathrm{~S}, \mathrm{AC}, \mathrm{CI} \\
\text { DI, CR: } 17.5: 1, \mathrm{RP}: 4.4 \\
\text { kW, RS: } 1500 \mathrm{rpm}\end{array}$ & $\begin{array}{l}\text { External Mixture } \\
\text { Preparation }\end{array}$ & Diesel & EGR $(0 \%$ and $10 \%)$ & $\begin{array}{l}55 \% \mathrm{NOx} \text { decreased, } 80 \% \text { smoke } \\
\text { decreased, } \mathrm{HC} \text { and } \mathrm{CO} \text { were } \\
\text { increased. }\end{array}$ \\
\hline
\end{tabular}




\section{CONCLUSIONS}

Chemical kinetics plays a dominant role in HCCI combustion. Based on this review, almost all researchers have obtained simultaneous reduction in negligible amount of NOx and PM, with increase in HC and CO emission compared to S.I and C.I combustion [17-25].

Optimum running conditions will overcome the difficulties faced in combustion phasing control, cold start problem and homogenous charge preparation. In C.I engines with minor modifications HCCI combustion can be attained with significant reduction in Nox and PM emission, with almost same performance as conventional C.I engine.

\section{REFERENCE}

1. Pucher GR, Gardiner DP, Bardon MF, Battista V. Alternative combustion systems for piston engines involving homogeneous charge compression ignition concepts - a review of studies using methanol, gasoline and diesel fuel. SAE technical paper $962063 ; 1996$.

2. Noguchi M, Tanaka Y, Tanaka T, Takeuchi Y. A study on gasoline engine combustion by observation of intermediate reactive products during combustion. SAE technical paper 790840; 1979.

3. Heywood JB (1988) Internal combustion engine fundamentals.McGraw-Hill Inc, New York. ISBN 0-07-028637-X.

4. Onishi S, Jo SH, Shoda K, Jo PD, Kato S (1979) Active thermoatmosphere combustion (ATAC)-a new combustion process for internal combustion engines, SAE Paper 790501.

5. Atkins MJ, Koch CR (2005) The effect of fuel octane and dilutent on homogeneous charge compression ignition combustion. ProcInstMechEng D J AutomobEng 219(5):665-675

6. Alkidas AC. combustion advancements in gasoline engines. Energy Convers.Manage 2007;48:2751-61.

7. Dec JE. Advanced compression-ignition engines-understanding the in-cylinder processes. Proc Combust Inst 2009;32:272742.

8. Lu X, Han D, Huang Z. Fuel design and management for the control of advanced compression-ignition combustion modes. Prog Energy Combust Sci 2011;37:741-83.

9. Pravin Kumar \& A. Rehman, Performance and Emission Characteristics of Dual Injection in Compression Ignition (CI) Engine, International Journal of Automobile Engineering Research and Development (IJAuERD), Volume 4, Issue 6, November - December 2014, pp. 13-26

10. Saxena S, Bedoya ID. Fundamental phenomena affecting low temperature combustion and HCCI engines, high load limits and strategies for extending these limits. Prog Energy Combust Sci. 2013;39(5):457-88.

11. Yao M, Zheng Z, Liu H. Progress and recent trends in homogeneous charge compression ignition (HCCI) engines. Prog Energy Combust Sci 2009;35:398-437.

12. Starck L, Lecointe B, Forti L, Jeuland N. Impact of fuel characteristics on HCCI combustion: performances and emissions. Fuel 2010;89:3069-77.

13. Bendu H, Murugan S. Homogeneous charge compression ignition (HCCI) combustion:mixture preparation and control strategies in diesel engines. RenewSustain Energy Rev 2014;38:732-46.

14. Imtenan S, Varman M, Masjuki HH, Kalam MA, Sajjad H, Arbab MI, Fattah IMR.Impact of low temperature combustion attaining strategies on diesel engine emissions for diesel and biodiesels: a review. Energy Convers Manage 2014;80:329-56. 
15. Johansson B. Fuels and Combustion, chap 1 in biofuels from lignocellulosicbiomass:innovations beyond bioethanol. Michael Boot, editor. 1st ed. Wiley-VCH Verlag GmbH \& CO; 2016.

16. Hasan MM, Rahman MM. Homogeneous charge compression ignition combustion:advantages over compression ignition combustion, challenges and solutions.Renew Sustain Rev 2016;57:282-91.

17. Musculus MPB, Miles PC, Pickett LM. Conceptual models for partially premixed low-temperature diesel combustion. Prog Energy Combust Sci 2013;39(2-3):246-83.

18. GomesntunesJ,MikalsenR,RoskillyA.AninvestigationofhydrogenfuelledHCCIengineperformanceandoperation.IntJHydrogenEnergy 2008;33:5823-8.

19. Swami NathanS,MallikarjunaJ,RameshA.Effects of charge temperature and exhaustgasre-circulationon combustion and emission characteristics of an acetylene fuelled HCCIengine.Fuel2010;89:515-21.

20. Ganesh D,NagarajanG, GanesanS. Experimental investigation of homo-geneous charge compression ignition combustion of biodiesel fuel with external mixture formation in a CI engine.EnvironSciTechnol2014;48:3039-46.

21. Jiménez-EspadaforFJ,TorresM,VelezJA,CarvajalE,BecerraJA. Experimental analysis of low temperature combustion mode with diesel and biodiesel fuels: a method for reducing NOx and soot emissions.Fuel Process Technol2012;103:57-63.

22. Singh G, SinghAP, AgarwalAK. Experimental investigations of combustion, performance and emission characterization of biodiesel fuelled HCCI engine using external mixture formation technique.SustainEnergTechnolAssess 2014;6:116-28.

23. Shi L,CuiY, DengK, PengH, ChenY. Study of low emission homogeneous charge compression ignition(HCCI) engine using combined internaland external exhaust gas recirculation(EGR).Energy2006;31:2665-76.

24. Ganesh D, NagarajanG. Homogeneous charge compression ignition(HCCI) combustion of diesel fuel with external mixture formation.Energy 2010;35:148-57.

25. Singh AP, AgarwalAK. Combustion characteristics of diesel HCCI engine: anExperimental investigation using external mixture formation technique. Appl Energy2012;99:116-25.

26. Ganesh D, NagarajanG, Mohamed IbrahimM. Study of performance, combustion and emission characteristics of diesel homogeneous charge compression ignition(HCCI) combustion with external mixture formation. Fuel 2008;87:3497-503. 
